\title{
PARTNERSHIP BETWEEN UNIVERSITIES AND THE LOCAL HEALTHCARE SYSTEM TO BENEFIT THE TOWN OF BURITICUPU, A POOR COMMUNITY IN THE STATE OF MARANHÃO, BRAZIL PARCERIA ENTRE UNIVERSIDADE PÚBLICA E SISTEMA DE SAÚDE LOCAL EM FAVOR DE COMUNIDADE CARENTE DO INTERIOR DO MARANHÃO, BRASIL
}

\author{
Marcelo El Khouri, Leandro Savoy Duarte, Janos Valery Gyuricza, and Carlos \\ Eduardo Pereira Corbett
}

The Faculty of Medicine, University of São Paulo (FMUSP) in partnership with the Brazilian Ministry of Health, the local healthcare system and the Federal University of Maranhão (UFMA), took the Bandeira Científica project to the town of Buriticupu, located in the state of Maranhão, Brazil (Fig. 1). The Bandeira Científica project consists of an annual expedition, each year to different part of Brazil, directed by FMUSP faculty members and executed by FMUSP medical students. Objectives are to train medical students in primary healthcare to deprived communities and to offer such primary healthcare as well as educational lectures. The Bandeira also performs epidemiological studies. On this occasion, Buriticupu, in the backlands of the state of Maranhão was selected as the target town.

Buriticupu has a population of 50,059 inhabitants, but lacks basic sanitation and education, the latter provided mainly by an insufficient set of public schools. Illiteracy is predominant in adults over the age of twenty. The last Demographic Census, collected in the year of 2000 indicated illiteracy rates of $63,8 \%$ among children over the age of 10 .

UFMA provides basic
Através da parceria com o Ministério da Saúde, do Sistema de Saúde Público local e com o apoio da Universidade Federal do Maranhão (UFMA) foi possivel a viabilização do projeto Bandeira Científica da Faculdade de Medicina da Universidade de São Paulo na cidade de Buriticupu, localizada no interior do Estado do Maranhão (Fig. 1), com população estimada de 50.059 habitantes segundo censo demográfico do IBGE de 2000. O projeto é organizado por acadêmicos de medicina da USP e visa levar assistência primária e palestras educativas às populações carentes, além de promover trabalhos epidemiológicos relacionados com a região assistida.

A cidade possui saneamento básico escasso, a rede de ensino é precária, proporcionada principalmente por escolas públicas. $O$ analfabetismo é predominante nos adultos acima de 20 anos (dados do Censo Demográfico 2000 demonstram uma taxa de alfabetização de 63,8\% nos moradores com mais de 10 anos). A UFMA já atuava na cidade através de um posto de saúde, atendendo regularmente as quatro doenças

Figure 1 - Buriticu and the State of Maranhão in a map of Brazil. Figura 1 - Localização do Município de Buriticupu, Maranhão, Brasil. 
medical support to combat the four most endemic diseases (malaria, Hansen's disease, leishmaniasis and tuberculosis) in the form of diagnosis, follow up and treatment, including distribution of medication provided by the Brazilian Ministry of Health.

The medical assistance offered by Bandeira Científica focused on general practice, but some specific areas

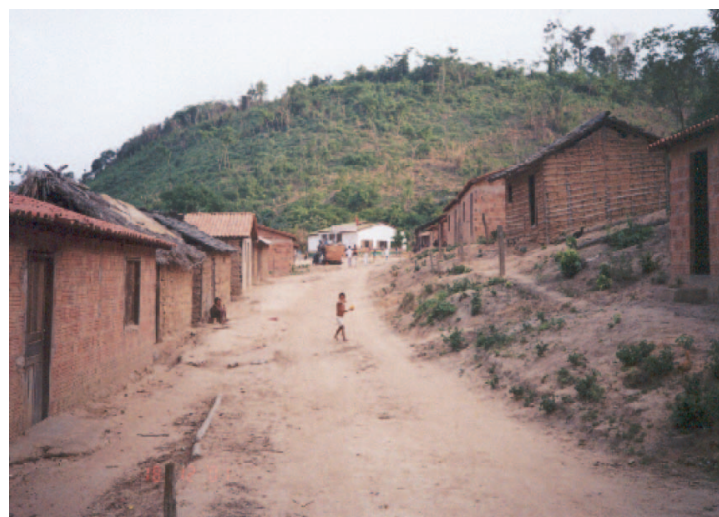

Figure 2 - Typical image of rural Buriticupu.
Figura 2 - Imagem típica encontrada nas áreas rurais.

região (malária, hanseníase, leishmaniose e tuberculose), diagnosticando, acompanhando o tratamento e distribuindo medicação fornecida pelo Ministério da Saúde.

A assistência médica oferecida pela Bandeira foi baseada em consultas em ambulatório geral e algumas especialidades como dermatologia, pediatria, infectologia e psiquiatria such as dermatology, pediatrics, infectology and psychiatry were also contemplated. Consultation was by appointment, organized by local healthcare workers. Patients were triaged according to their initial complaints, followed by an interview consisting of demographic questions, which preceded medical consultation. This was performed by medical students under constant supervision from experienced physicians and faculty members. Medication was distributed after consultation if necessary.

In this manner 21 rural areas of the town were covered, totaling 3,428 interviewed patients. Laboratory tests were performed, including 340 blood tests for a Hepatitis B and C research program. A total of 46 biopsies and 219 Papanicolaou smear tests were also performed. The most frequent diagnostic findings were parasitic intestinal infestations (12\% of prevalence), vulvovaginal infections $(10,2 \%)$, muscular pain $(9,5 \%)$, headache $(8,4 \%)$ and scabies $(7 \%)$.

Furthermore, 7 classes were given to the local heathcare workers and to the general population. Attendants received certificates provided by Bandeira Científica. Classes covered malaria, Hansen's disease, tuberculosis, leishmaniasis, parasitic intestinal infections, water care and sanitation, dengue fever, contraceptive methods, cancer prevention, first aid, pre-natal care, drugs, smoking and STD/AIDS.

The project lasted 10 days, which was considered less than necessary to satisfy local demand, but enough to develop an awareness about healthcare rights and duties, to stimulate local leaderships towards improvement and optimization of resources. Regions with a shortage of healthcare workers were visited and our contact was often a unique opportunity for citizens to have contact with a medical professional.

Students participating in the Bandeira Cientifica project are invariably challenged to cope with some of the difficulties inherent to these poor communities; upon returning home to São Paulo, a new set of concepts occupies their minds. As in other occasions, this issue of the Bandeira abrangendo as zonas urbana e rural. As consultas foram pré-agendadas pelos agentes de saúde locais (ACS), passaram por triagem, preencheram um cadastro e foram atendidos pelos acadêmicos, sob constante supervisão por médicos e professores. Todo atendimento foi seguido pela entrega de medicamentos.

Dessa forma, conseguiu-se abranger 21 localidades rurais e realizando 3.428 atendimentos, coletar cerca de 340 amostras de sangue para pesquisa de hepatite $B$ e $C, 46$ biópsias e realização de 219 exames de Papanicolaou. Os principais achados diagnósticos incluíram verminose $(12 \%$ de prevalência), corrimento vaginal (10,2\%), dor osteomuscular (9,5\%), cefaléia $(8,4 \%)$ e escabiose (7\%).

Além disso, 7 palestras foram ministradas aos profissionais de saúde locais e à população leiga com posterior entrega de certificados confeccionados pela Bandeira $\mathrm{Ci}$ entífica. Os temas versaram sobre malária, hanseníase, tuberculose, leishmaniose, verminoses, com ênfase em cuidados com água, dengue, métodos contraceptivos, prevenção do câncer, primeiros socorros, cuidados no pré-natal, drogas, tabagismo e DST/AIDS.

As ações ocorreram durante 10 dias, aquém do necessário para atender as demandas locais, mas suficiente para o desenvolvimento de sensibilização dos moradores quanto ao acesso aos recursos de saúde, estímulo das lideranças locais para implementação de melhorias e racionalização do uso de recursos. Foram visitadas regiões com poucos profissionais de saúde e o contato com nossa equipe muitas vezes foi uma rara oportunidade para esses cidadãos obterem consulta, medicação ou exame.

$O$ acadêmico que participa da Bandeira é desafiado a enfrentar as dificuldades dessas regiões mais carentes, retornando repleto de questionamentos. Em contrapartida, aos habitantes visitados, a Bandeira oferece uma atenção imediata, ouvindo suas queixas, fornecendo medicações $e$ coletando exames que são preconizados pelo Ministério da Saúde em programas de cobertura universal. 
Cientifica provided a reasonable health evaluation of the needy inhabitants of the backlands of Maranhão.

A number of actions were adopted in order to try to maintain the health care procedures introduced during the Bandeira Científica:

1- a data bank was constructed, comprising information of all attended patients;

2- a written report with the results of all exams was delivered to Secretary of Health of Buriticupu;

3- a proposal was submitted for the restructuring of the healthcare system according to Brazilian Family Healthcare Program and Healthcare Workers Program;

4- a donation of materials and medications was made;

5- a proposal was submitted for the rebuilding the local hospital;

6- proposals were submitted for the implementation of a rural internship system for medical students of UFMA, to maintain the medical support prevalent during the Bandeira Científica;

7- a schedule was organized for the return of doctors from UFMA, in order to establish a monthly visit to patients, including those attended during the Bandeira Científica.

Thus, the partnership between FMUSP, UFMA and local health authorities of Buritipucu achieved some measure of success in its goal of enhancing the local healthcare system structure and strengthening the link between public university and community, bonding professors, students and local residents with respect to a voluntary system of welfare practice.
Dentre as ações feitas visando a sustentabilidade do projeto em Buriticupu, destacam-se a formação de um banco de dados com o cadastro de todos os pacientes atendidos e um relatório com os resultados obtidos cedidos junto à Secretaria de Saúde de Buriticupu; a proposta de reestruturação do sistema de saúde em concordância com o modelo do Programa de Saúde da Família (PSF) e Programa de Agentes Comunitários de Saúde (PACS); a doação de materiais, medicamentos e uma proposta de reestruturação do Hospital Municipal de Buriticupu; proposta de implantação do Estágio Rural para acadêmicos de medicina da UFMA, dando seguimento aos atendimentos realizados durante a Bandeira; e por fim auxiliar na programação do retorno dos médicos da UFMA ao Núcleo em Buriticupu de forma a prestar atendimento e continuidade mensal aos pacientes, incluindo aqueles atendidos pela Bandeira Científica.

Assim, pretendeu-se reforçar a estrutura do Sistema de Saúde público local e estreitar os vínculos entre universidade pública e a comunidade, unindo professores, alunos e residentes locais na prática do bem comum. 